\title{
Estrogen receptors and their implications in colorectal carcinogenesis
}

\section{Francesco Caiazza ${ }^{1,2}$, Elizabeth J. Ryan ${ }^{1,2}$, Glen Doherty ${ }^{1,2}$, Desmond C. Winter ${ }^{1,3}$ and Kieran Sheahan ${ }^{1,2,4}$ *}

${ }^{1}$ Centre for Colorectal Disease, Saint Vincent's University Hospital, Dublin, Ireland

${ }^{2}$ School of Medicine and Medical Science, University College, Dublin, Ireland

${ }^{3}$ Department of Surgery, St. Vincent's University Hospital, Elm Park, Dublin, Ireland

${ }^{4}$ Department of Pathology, Saint Vincent's University Hospital, Dublin, Ireland

Edited by:

Rupert Langer, University of Bern,

Switzerland

Reviewed by:

Shuji Ogino, Dana-Farber Cancer Institute, USA

Savio George Barreto, Medanta, The Medicity, India

\section{${ }^{*}$ Correspondence}

Francesco Caiazza and Kieran

Sheahan, Department of

Histopathology, Saint Vincent's

University Hospital, Elm Park, Dublin

4, Ireland

e-mail: francesco.caiazza@gmail.com;

k.sheahan@st-vincents.ie
Upon binding their cognate receptors, ER $\alpha$ (ESR1) and ER (ESR2), estrogens activate intracellular signaling cascades that have important consequences for cellular behavior. Historically linked to carcinogenesis in reproductive organs, estrogens have also been implicated in the pathogenesis of different cancer types of non-reproductive tissues including the colon. ER $\beta$ is the predominant estrogen receptor expressed in both normal and malignant colonic epithelium. However, during colon cancer progression, ER $\beta$ expression is lost, suggesting that estrogen signaling may play a role in disease progression. Estrogens may in fact exert an anti-tumor effect through selective activation of pro-apoptotic signaling mediated by $E R \beta$, inhibition of inflammatory signals and modulation of the tumor microenvironment. In this review, we analyze the estrogen pathway as a possible therapeutic avenue in colorectal cancer, we report the most recent experimental evidence to explain the cellular and molecular mechanisms of estrogen-mediated protection against colorectal tumorigenesis, and we discuss future challenges and potential avenues for targeted therapy.

Keywords: estrogen, estrogen receptor, colorectal cancer, tumor immunology, tumor microenvironment

\section{INTRODUCTION}

Estrogens (including estrone, estriol, and the biologically active metabolite $17 \beta$-estradiol) are cholesterol-derived steroid hormones that are produced by aromatization of androgens primarily in the ovary but also in other tissues (including muscle, adipose, and nervous tissues). Estrogens play a central role in controlling sexual behavior and reproductive functions, and are important in the physiology of both men and women. Estrogens regulate the development and homeostasis of a wide range of tissues and organs, playing a crucial role in the cardiovascular, nervous, and immune systems, as well as in bone metabolism (1). As a result, estrogens have been implicated in numerous pathophysiological conditions including cancer (2). Historically linked to carcinogenesis in reproductive tissues (ovary, uterus, and breast in women; prostate in men), estrogens are also implicated in different cancer types of non-reproductive tissues like the lung and the gastrointestinal system. The protective role of estrogens against carcinogenesis specifically in the colon was the subject of a previous review (3). Here, we aim to extend our analysis of estrogen signaling in the colon, including the role of the tumor microenvironment and immune evasion mechanisms; we also aim to discuss the potential role of manipulating the estrogen pathway as a therapy in colorectal cancer (CRC).

\section{ESTROGEN RECEPTORS: STRUCTURE, FUNCTION AND MECHANISIMS OF ACTION}

Estrogens bind to two different estrogen receptors (ERs), ESR1 (ERalpha, or ER $\alpha$ ) and ESR2 (ERbeta or ER $\beta$ ), both members of the nuclear receptor family (hereafter referred to as $\mathrm{ER} \alpha$ and $\mathrm{ER} \beta$ ). Like other members of this family, ERs are modular proteins organized in functional domains (N-terminal domain, DNA-binding domain, hinge region, ligand-binding C-terminal domain) that interact to mediate ligand-dependent gene expression $(4,5)$. ER $\alpha$ and ER $\beta$, which are encoded by two separate genes (ESR1 and ESR2) located on different chromosomes, share a high degree of sequence homology particularly in the DNA-binding region $(97 \%$ homology) and to a lesser extent in the ligand-binding region (59\% homology), which underlies their shared mechanism of action with differences in their specificities and sensitivities for different ligands. ER $\alpha$ and ER $\beta$ also have markedly different tissue- and organ-specific expression patterns (5). In the classical mechanism of action, estrogen-bound ERs located in the cytoplasm undergo conformational changes that allow them to dissociate from scaffolding heat shock proteins (Hsp90 and Hsp70), to dimerize and to translocate to the nucleus, where they can bind to specific DNA sequences (ERE) in the promoter regions of target genes to modulate their expression $(4,6)$. In addition, ERs can also bind to other transcription factors including Sp1, AP-1, and NFKB, allowing them to extend their influence to genes that do not contain ERE sequences in their promoter regions. Both ER $\alpha$ and ER $\beta$ interact with receptor tyrosine kinases, scaffolding proteins, guanine nucleotide exchange $(\mathrm{G})$-proteins, as well as other intracellular signaling proteins, allowing them to activate a wide range of cytoplasmic signaling pathways, a process, which is independent of transcription but that can ultimately impact on latent gene expression $(5,7,8)$. The cumulative action of estrogens (as well as 
other steroid hormones) ultimately results from the integration of signaling originating from receptors located in different cellular compartments (9). This provides a mechanistic explanation for the delicate fine-tuning of responses to hormonal stimulation that occurs in a tissue-specific fashion and depending on the cellular milieu.

$\mathrm{ER} \alpha$ and $\mathrm{ER} \beta$ show differences in their biological functions dependent on both nuclear and extra-nuclear signaling. Generally, $\mathrm{ER} \alpha$ promotes proliferative signaling through differential expression of pro- and anti-apoptotic proteins, as well as cyclin D1 to promote cell cycle transition $(10,11)$. On the other hand, ER $\beta$ acts as a dominant regulator, inducing a reduction in ER $\alpha$-mediated gene expression (when the two receptors are co-expressed) with a consequent negative effect on cell proliferation (12). ER $\beta$ is also able to exert standalone anti-proliferative effects (in the absence of $E R \alpha$ ) by activating pro-apoptotic signaling through the p38/MAPK pathway $(11,13)$.

\section{ESTROGEN RECEPTORS: ROLE IN NORMAL PHYSIOLOGY AND CANCER}

The individual contributions of $\operatorname{ER} \alpha$ and $\operatorname{ER} \beta$ in development and physiology have been elucidated with the use of $\mathrm{ER} \alpha^{-I-}, \mathrm{ER} \beta^{-I-}$, and double knockout mice (14). These mice survived to adulthood with a variable degree of phenotypic abnormalities in different tissues, including ovaries, uterus, mammary gland, prostate, testis, bone, and brain. These phenotypic alterations are ER type-specific, and they do not occur in the early phases of organ development. Both ERs are necessary for the development and proper function of the ovaries. ER $\alpha$ is involved in the development of the uterus and the mammary gland, as well as in bone physiology and male fertility, whereas ER $\beta$ is important for neuronal development (particularly in the somatosensory cortex) (4). Estrogens have a physiological role in the regulation of ion channels in epithelia of kidney, intestine, and lung to regulate whole body fluid and electrolyte balance (15). Estrogen has a physiological role as a regulator of $\mathrm{Cl}^{-}$secretion in the colon, contributing to the salt and water retention observed during the high estrogen states $(16,17)$.

Consistent with their role in normal physiology, estrogens and ERs have been implicated in numerous human diseases including osteoporosis, obesity, cardiovascular and neurodegenerative diseases, and immune system disorders (2, 4, 18). Furthermore, and not surprisingly given the spectrum of their downstream signaling targets, estrogens contribute to cancer development and progression in different tissue types, mainly in endocrine-related reproductive tissues [mammary gland (19), ovary (20), uterus (21), and prostate (22)] and also in non-endocrine-related tissues [lung (23) and colon (24)]. The influence of ER $\alpha$-mediated proliferative signaling has been extensively studied in the context of breast cancer, where pharmaceutical strategies to inhibit such signaling have been a clinical success in the past 20 years $(19,25)$. Inhibition of estrogenic signaling is achieved either through the use of selective estrogen receptor modulators (SERM) like tamoxifen and raloxifene, or through inhibition of estrogen synthesis via aromatase inhibitors. Proliferative signaling originating from $\mathrm{ER} \alpha$ is also involved in the pathophysiology of non-reproductive tissues. For example, in the lung, ER $\alpha$ increases cellular proliferation of normal lung fibroblasts and lung tumor cell lines in vitro and tumor growth in immunocompromised mice (26), and is a negative prognostic marker in non-small-cell lung cancer independently of gender (27). While ER $\alpha$ promotes proliferation of prostate cancer cells, estrogen action through ER $\beta$ is antiproliferative and anti-inflammatory in the prostate (28). ER $\beta$ has anti-proliferative effects in breast cancer when co-expressed with $\mathrm{ER} \alpha$, and studies show that loss of ER $\beta$ expression through promoter hypermethylation occurs frequently in ductal breast cancer (29). ER $\beta$ has also putative anti-proliferative effects in the ovary and endometrium $(30,31)$. Beside this, the role of $\operatorname{ER} \beta$ in nonreproductive tissues has been studied particularly in the context of gastrointestinal malignancies.

\section{EVIDENCE FOR ESTROGEN RECEPTOR SIGNALING IN COLON CANCER}

$\mathrm{ER} \beta$ is the predominant estrogen receptor expressed in both normal and malignant colonic epithelium, with limited or no expression of ER $\alpha$ observed in the colon (32). The expression of ER $\beta$ is reduced during colonic tumorigenesis as compared to normal tissue $(12,33,34) . E R \beta$ is associated with stage and grade of disease, and an inverse relationship between ER $\beta$ expression and tumor progression has been reported in cell lines and clinical samples (35-37). It is therefore hypothesized that estrogen-mediated signaling exerts a protective role in CRC, further understanding of this may benefit cancer prevention and also provide additional therapeutic options for ER $\beta$-positive tumors. The evidence for this anti-tumorigenic effect comes from a plethora of different studies, which are reviewed below.

\section{EPIDEMIOLOGICAL EVIDENCE FOR THE ROLE OF STEROID HORMONES IN CRC}

The incidence of CRC is higher in men than it is in women (38). With the exception of New Zealand and the USA (where rates are decreasing for both sexes), incidence rates are increasing in men while remaining steady among women $(39,40)$. Although not originally designed to investigate CRC risk, the Women Health Initiative study demonstrated that use of hormone replacement therapy (HRT) in post-menopausal women was associated with a $30 \%$ decreased incidence of CRC $(41,42)$. A number of other observational studies have addressed this question [summarized in Ref. (43)] and the majority report a decreased incidence of CRC among HRT users (although some studies do not report any difference), and a 30-60\% decrease in CRC-related mortality. Interestingly, a recent study of 503 post-menopausal women has highlighted a role for ER $\beta$ in mediating the protective effects of HRT. Decreased CRC risk was associated with duration of HRT use specifically in ER $\beta$-positive patients (OR for each 5 years interval: 0.87, 95\% CI: $0.77-0.99$ ) but not in ER $\beta$-negative patients (OR: 1.02, 95\% CI: $0.91-1.15$ ) (44). This is an example of a relatively novel area of epidemiologic research that has been termed molecular pathological epidemiology (45). This type of study associates an etiological factor (like an exposure factor) to specific molecular changes in tumors, and analyzes interactive effects with the aim of gaining insights into the carcinogenic process. A number of these studies have analyzed in detail the exposure of post-menopausal women to hormone therapy, and have shown that this is associated with reduced risk of specific sub-sets of CRC, according to 
the expression of cell cycle regulators, DNA methylation, somatic mutations (BRAF and KRAS), and microsatellite instability (MSI) (46-49).

Incidence of CRC varies greatly by geographical region, with the highest rates seen in developed countries (Australia, New Zealand, Western Europe, and North America) and lowest rates in developing countries, particularly in Africa and Asia (38). These differences reflect distribution patterns for known risk factors for CRC (like smoking, obesity, and consumption of red meat), including differences in diet, e.g., Asian countries extensively use soy products containing phytoestrogens. In a recent meta-analysis of retrospective studies, soy consumption was found to be associated with a $21 \%$ decreased risk of CRC in women but not in men (50), a finding that might be related to the fact that soy supplementation is more effective when combined with estrogens in vivo (51). Furthermore, when people migrate from an Asian country to the U.S., incidence of CRC in the migrants begins to rise to the average of the U.S. (52).

Among the characteristics that are associated with the so-called western lifestyle, obesity is an important established risk factor for CRC in both men and women, although reported hazard ratios vary greatly according to whether body mass index (BMI) or waist circumference (WC) is used as a surrogate measure $(53,54)$. The prevalence of adenoma and advanced polyps is higher in men than women in all age groups except for people older than 70 years, and a positive association between BMI and the prevalence of colonic adenoma and advanced polyps was shown in young individuals of both gender and in premenopausal women according to hormonal status (53). This further supports the role that steroid hormones play in linking obesity to the increased risk of CRC, which has been previously demonstrated in animal models (55). Adipose tissue contributes to extra-gonadal testosterone aromatization and estrogen production. Adipose tissue is also an estrogen target tissue, and adipocytes express both $\mathrm{ER} \alpha$ and $\mathrm{ER} \beta$, where they are involved in estrogen-mediated control of adipogenesis, lipogenesis, lipolysis and adipocyte proliferation (18). Obesity results in metabolic changes that can in turn promote colorectal carcinogenesis, and steroid hormones also modulate some of these mechanisms. For example, hyperinsulinemia and insulin resistance are associated with obesity, and insulin/insulin-like growth factor (IGF-I) signaling promotes tumorigenesis (56). Mitogenic leptin is also increased in obese patients $(53,57)$, and estrogens can regulate leptin through $\mathrm{ER} \alpha$ (58). A decrease in anti-inflammatory adipokines is also linked to both obesity and risk of CRC, although in a cohort study of post-menopausal women this did not reach statistical significance in multivariate analysis (57). Obesity overall is characterized by low-grade chronic inflammation and reduced immunity, which also contribute to tumorigenesis (53). Furthermore, epidemiological studies have also linked physical activity to the risk of different cancers including CRC, demonstrating that increased exercise leads to reduced estrogen levels in postmenopausal women and a modulation of menstrual function in premenopausal women (59). Physical activity improves insulin resistance, reduces hyperinsulinemia, and reduces risk for diabetes; it might also reduce systemic inflammation alone or in combination with reduction in body weight through reducing inflammatory cytokines in adipose tissue (59).

\section{CLINICAL EVIDENCE FOR THE ROLE OF ER $\beta$ IN CRC PROGRESSION}

The expression of ER $\beta$ declines during tumor progression $(34,60)$, and analysis of clinical samples provided initial evidence that the reduced expression of $\operatorname{ER} \beta$ could relate to tumor stage and grade, and to other characteristics of poor prognosis (including poorly differentiated tissue, vascular invasion, and decreased apoptotic index $)(32,33,36)$. In a recent analysis of 1262 patients, expression of ER $\beta$ by immunohistochemistry correlated with prognosis in CRC: decreased expression was found in larger tumors of higher grade, and expression levels were also inversely correlated with Dukes stage. ER $\beta$ negativity was associated with a $54 \%$ increased risk of CRC-specific death, and a poorer disease-free survival (DFS) (35). Single-nucleotide polymorphisms (SNPs) located in the $5^{\prime}$ regulatory region of the ER $\beta$ gene (but not of $\mathrm{ER} \alpha$, progesterone receptor, or androgen receptor) were associated with improved survival after a diagnosis of CRC. These SNPs could be markers of receptor isoforms expression or CpG island methylation and transcriptional inactivation of ER $\beta$ (61). Furthermore, members of p160 ER co-activator superfamily AIB1 (SRC3/NCoA3) and TIF2 (SRC-2), which interact with ER $\beta$ to mediate transcriptional activity, were up-regulated in adenomas and carcinomas compared to normal tissue; AIB1 was also associated with increased overall survival in a cohort of 110 CRC patients (62).

\section{PRE-CLINICAL EVIDENCE OF THE ROLE OF ER $\beta$ IN CRC}

A number of in vitro studies supporting an inhibitory role for ER $\beta$ in CRC progression have been previously described (3). Recently, reported studies in mice have provided some in vivo evidence for the role of ER $\beta$ in CRC. Analysis of colonic tissue in ER $\beta^{-1-}$ mice showed that loss of ER $\beta$ leads to hyper-proliferation, dedifferentiation, decreased apoptosis, and disruption of epithelial tight junctions; surprisingly no tumor formation was reported as hyper-proliferative cells moved faster to the surface of colonic crypts and were subsequently shed in the lumen (63). Saleiro and colleagues used the azoxymethane/dextran sodium sulfateinduced mouse model of colitis-associated CRC to show increased severity of clinical colitis in the absence of ER $\beta$. This was coupled to increased inflammation and higher grade of dysplasia specifically in the early phase of tumor development, suggesting that ER $\beta$ might delay inflammation and neoplastic transformation (64). Giroux et al. crossed $\mathrm{ER} \beta^{-/-}$mice with $\mathrm{Apc} \mathrm{Min}^{\mathrm{M}+} \mathrm{C} 57 \mathrm{BL} / 6 \mathrm{~J}$ mice to obtain $\mathrm{ER} \beta^{-1-} \mathrm{Apc} \mathrm{Min}^{\mathrm{M}+}$ mice, which showed increased number and size of polyps, and tumors that were significantly larger than those in control Apc ${ }^{\mathrm{Min} /+}$ mice. (65). These data suggest that loss of $\operatorname{ER} \beta$ alone might not be sufficient to promote colorectal carcinogenesis, but that instead it would confer selective advantage to transforming epithelial colonocytes by eliminating a protective mechanism against genotoxic stress in the early phases of cellular transformation, therefore accelerating tumorigenesis.

As there are numerous downstream signaling pathways modulated by $\mathrm{ER} \beta$, there are a number of potential mechanisms by which ER $\beta$ exerts this protective effect. Gene expression profiles of $\mathrm{ER} \beta^{-/-} \mathrm{Apc}$ Min/+ mice suggested that modulation of the TGF- $\beta$ signaling pathway contributed to the protective role of estrogens on intestinal tumorigenesis (65). Ectopic expression of ER $\beta$ in SW480 CRC cells resulted in inhibition of proliferation and cell cycle arrest in $\mathrm{G}_{1}$ phase, which was dependent on decreased $c-M y c$ 
and altered expression of different cell cycle proteins. Furthermore, when ER $\beta$-transfected SW 480 cells were implanted in the fat pad of SCID/Beige mice in the presence of estrogen, ER $\beta$ over-expression resulted in a $65 \%$ reduction in tumor weight (37). Similarly, when ER $\beta$-overexpressing HCT- 116 cells were xenografted into BALB/cnu nude mice, there was an $18 \%$ reduction in tumor growth, with a greater tumor reduction (89\%) seen in combination with raloxifene (66). Apc $\mathrm{Min}^{\mathrm{C}+}$ mice treated with a SERM (raloxifene) or an anti-estrogenic compound (Gonadorelin) showed a $65-75 \%$ inhibition in intestinal tumor multiplicity and size, and a $94-98 \%$ inhibition of polyps $>2 \mathrm{~mm}$ in size, with decreased expression of $\beta$-catenin, cyclin D1, laminin $1 \mathrm{~b}$, and stem-like cells markers (67). Using the azoxymethane/dextran sodium sulfate model, Armstrong and colleagues showed that estrogen treatment reduced expression of ER $\beta$ while increasing ER $\alpha$ (68), and a similar finding was previously reported in rats treated with soy isoflavonoids (69), suggesting that the ratio of $E R \beta / E R \alpha$ might have clinical implications in protecting against CRC (70). However, differential expression of ER $\beta$ isoforms in different tissues and organs, or during tumor progression, may also contribute to the outcome of estrogen signaling.

\section{ER $\beta$ ISOFORMS AND THEIR ROLE IN COLORECTAL CANCER}

Four alternative isoforms of $\operatorname{ER} \beta$ have been described so far $(\mathrm{ER} \beta 2 / \mathrm{ER} \beta \mathrm{cx}, \mathrm{ER} \beta 3, \mathrm{ER} \beta 4, \mathrm{ER} \beta 5)$, arising from alternative splicing of the last coding exon of the receptor; these proteins have a truncated or otherwise altered C-terminal domain (12). These isoforms were initially cloned from a human testis cDNA library and shown to have different pattern of tissue distribution (71). The Cterminal region of the ER contains the ligand-binding domain and is also involved in transcriptional activation, receptor dimerization, nuclear translocation and interaction with transcription coregulators (4). Therefore, modifications in this particular region can have a profound impact on the activity and biological function of ER $\beta$. A recent study addressed the functional role of ER $\beta$ isoforms, showing that ER $\beta 2-4-5$ are lacking intrinsic liganddependent transactivation activity, making ER $\beta 1$ (wild-type) the only functional receptor isoform. However, ER $\beta 2-4-5$ form heterodimers with ER $\beta 1$, and they can enhance transcriptional activity induced by $\operatorname{ER} \beta 1$ at physiological concentrations of estrogen (72). ER $\beta$ isoforms were identified in two CRC cell lines (HCT8 and HCT-116) by RT-PCR, with two more cell lines (DLD-1 and LoVo) reported negative for all isoforms (73). ER $\beta 2$ and ER $\beta 5$ were the predominant isoforms identified in 91 primary colorectal carcinoma samples by immunohistochemistry, using custommade antibodies raised against isoform-specific peptides in the C-terminal region (74). ER $\beta 2$ was decreased in tumor tissue compared to normal adjacent tissue, and associated with right-sided tumors and the presence of lymph node metastases, while ER $\beta 5$ was expressed in all tumor samples and also in a panel of 20 CRC cell lines (74). The specific role of ER $\beta$ isoforms in CRC is yet to be fully elucidated; however, it is plausible that the co-expression of different isoforms of the receptor (namely $\operatorname{ER} \beta 2$ and $\operatorname{ER} \beta 5$ ), even in the presence of low levels of full-length $\operatorname{ER} \beta$, would complicate the estrogen-mediated signaling involved in tumor suppression, and therefore, this needs to be taken into account when designing therapeutic strategies targeting the estrogen pathway.

\section{ESTROGEN RECEPTORS, TUMOR LOCATION, AND MICROSATELLITE INSTABILITY}

Colorectal cancers can arise from different regions of the colon, and their location impacts on their biological characteristics. Specifically, the right (proximal) colon and the left (distal) colon have different embryological origins (the midgut and the hindgut, respectively), which are reflected in differences in histopathology, molecular biological patterns, metastatic spread, and mutational profile of tumors (75-77). Proximal and distal tumors also have differences in their respective microbial flora, which can impact on tumor progression (78). Proximal tumors have a higher frequency of MSI (79), a pathway associated with loss of mismatch repair proteins resulting in accumulation of errors in DNA replication. Estrogens appear to be somehow linked to the left-right dichotomy in CRC: women develop more proximal, and men more distal colon and rectal cancers, and female sex is an independent predictor of proximal cancers (80). Furthermore, the incidence of proximal cancers in women increases with age, while the same is not observed in men (80). The reduction of ER $\beta$ expression is more prominent in proximal CRC $(21 \%)$ than in distal cases (7\%) (36), providing a putative rationale for the aforementioned gender disparities. MSI occurs more frequently on the right side of the colon, and in female patients (81), and a recent analysis reports an association of MSI with proximal cancers, hypermethylation (CIMP phenotype), and inflammatory subtype of CRC (79). Endocrine factors are associated with MSI tumors (82), with a significant interaction among age, sex, and MSI: women are more likely than men to have MSI tumors at an older age (82). This can be explained, at least in part, by the ability of estrogen to induce the expression of mismatch repair proteins (MLH1 and MSH2) via $\operatorname{ER} \beta$ (83).

Epidemiological differences have also been reported according to tumor location. Early ulcerative dysplastic lesions in the left colon are more likely to progress than those originating in the right colon (84). However, mortality rates are higher in right colon than in left-colon cancers $(75,79)$. Molecular pathological epidemiology studies have also provided some evidence that post-menopausal hormone therapy use could be associated with reduced risk of CRC selectively for distal tumors that are KRAS wild-type and MSI-low (48, 49).

The division between left and right colon might not be as dichotomous as previously thought, and instead represent a more homogenous continuum along the colon length (85). This is supported by linear changes in the distribution pattern of different molecular markers along the intestine $(86,87)$, and also by changes in recurrence rates according to tumor location (88). Furthermore, a recent study showed that within the right colon, there are differences between more distal and more proximal regions, where higher percentages of stage IV, node-positive or metastatic cancers, and higher mortality rates are reported in the more proximal portion (transverse colon) of the right colon (89).

Although more studies are needed to address the role of estrogens and differences in ER $\beta$ expression in different colon locations, the data reviewed here suggest that estrogen signaling might be (at least in part) responsible for the gender gap in proximal versus distal colon tumors and associated differences in biology and mortality rates. 


\section{ESTROGEN-MEDIATED REGULATION OF TUMOR MICROENVIRONMENT AND IMMUNE SURVEILLANCE}

Estrogen and other ER ligands modulate both innate and adaptive immunity, which is reflected in gender differences during autoimmunity (90). The contribution of inflammatory networks and immune-escape mechanisms in the tumor microenvironment in colorectal carcinogenesis is well established $(91,92)$. Yet, how ERdependent pathways contribute to the regulation of the inflammation within the tumor microenvironment is not well understood. Analysis of genome-wide gene expression changes in three CRC cell lines transfected with ER $\beta$ showed that IL-6 signaling pathway represented a significantly enriched sub-network, and RT-PCR confirmed the down-regulation of IL- 6 (as well as 10 different IL-6 target genes) by ER $\beta$ in SW480 cells (93). This has important potential consequences in modulating a tumor-promoting microenvironment, as IL-6 activate the STAT3 transcription factor in epithelial, myeloid cells, and myofibroblasts, promoting CRC tumorigenesis $(94,95)$. Different ER ligands regulate the homeostasis of bone marrow myeloid and lymphoid progenitors of dendritic cells (DC), and also modulate DC activation and production of inflammatory mediators (96). Estrogen signaling promotes the granulocyte macrophage-colony-stimulating factor (GM-CSF)-mediated differentiation of myeloid progenitor cells into $\mathrm{CD}_{1} \mathrm{lb}^{+} \mathrm{DC}$, through $\mathrm{ER} \alpha$-mediated activation of interferon regulatory factor 4 (IRF4) (97). Estrogen affects DC to regulate response to TLR agonists (98). Therefore another plausible mechanism by which estrogen could exert anti-tumorigenic effects in CRC would be through the regulation of DC-mediated immune surveillance, although this hypothesis needs to be addressed experimentally. Furthermore, the estrogen signaling in immune cells is complicated by multiple effects on different cell types, as estrogen is also known to have anti-inflammatory effects on monocytes and macrophages, and to enhance $\mathrm{CD}^{+} \mathrm{T}$ cell response (96). $\mathrm{ER} \beta$ is also involved in mediating anti-inflammatory responses. Using human osteosarcoma, U2OS cells expressing ER $\beta$ as a model, Cvoro and colleagues showed that both estradiol and ER $\beta$ selective agonists reduced the activation of 18 pro-inflammatory genes (including TNF- $\alpha$, IL-6, and CSF2) induced by TNF- $\alpha$ (99). This suggests that selective activation of ER $\beta$-mediated signaling might have a negative impact on tumorigenesis also through down-regulation of pro-tumorigenic inflammatory signaling in the tumor microenvironment. Moreover, cytokines produced by the tumor microenvironment could feedback on estrogen signaling through increased $3 \beta$-hydroxysteroid dehydrogenase gene expression, therefore inducing the biosynthesis of active steroid hormones from the inactive adrenal steroid dehydroepiandrosterone in peripheral target tissue (100). Finally, work with the $\mathrm{ER} \beta^{-1-}$ mouse model showed that a diet rich in estrogenic isoflavones and fiber could modify the composition of intestinal microbiota through ER $\beta$ in female mice, a finding, which have important consequences since the microbiota is known to influence local inflammation and intestinal tumorigenesis (101).

\section{ER SELECTIVE LIGANDS AND POTENTIAL AVENUES FOR TARGETED THERAPY}

Plant-derived flavonoids bind to both $\mathrm{ER} \alpha$ and $\operatorname{ER} \beta$ and are considered protective agents against endocrine-dependent tumors, among other potentially beneficial effects on human health. This provides a mechanistic explanation for some epidemiological evidence linking diet to CRC risk. In the specific context of colorectal carcinogenesis, naringenin $\left(5,7,4^{\prime}\right.$ trihydroxyflavone) and quercetin (2-3,4-dihydroxyphenyl-3,5,7trihydroxy-4H-1-benzopyran-4-one) induced apoptosis in CRC cells $(102,103)$. Both compounds activate the p38/MAPK signaling leading to activation of pro-apoptotic caspase 3 in DLD-1 colon cancer cells expressing ER $\beta$. Quercetin also increased the expression of the oncosuppressive protein PTEN and decreased cyclin D1 promoter activity (103). However, the potential medical use of flavonoids in cancer has not been addressed beyond pre-clinical studies.

Other chemical compounds used in industry and agriculture (termed xenoestrogens, or endocrine-disrupting chemicals) negatively impact on human health and have colorectal-specific effects. For example, bisphenol A (BPA) bind to both ER $\alpha$ and ER $\beta$ and act as an estrogen antagonist by inhibiting estrogen-induced pro-apoptotic signaling and gene expression (104). An increased research-driven awareness of the harmful effects of endocrine disruptors in recent years have resulted in policy changes concerning the use of these compounds in human activities, although the broad impact of this policy implementation on human disease is yet to be fully elucidated, and more basic research is needed to address mechanisms of action and physiological roles of xenoestrogens (105).

The development of ER subtype-selective ligands has been a very active field of research over the past 10 years. Consequently, a large number of ER $\beta$-specific agonists have been designed, although very few show potential as anti-cancer drug candidates (106). Isoquinolinone derivatives have been tested on different cancer cell lines and inhibit C-26 CRC cell proliferation. SR16388, another compound with ER $\beta$-specific activity, has shown promising properties for the treatment of non-small cell lung cancer, CRC, and androgen-independent prostate cancer (106).

\section{CONCLUSION}

Estrogen signaling has an anti-tumorigenic role in the colonic mucosa, through selective activation of pro-apoptotic signaling mediated by ER $\beta$, inhibition of inflammatory signals, and modulation of the tumor microenvironment and different immune surveillance mechanisms (Figure 1). Selective loss of ER $\beta$ expression during CRC progression highlights the importance of this oncosuppressive signaling, and provides difficulties in using this same signaling as a therapeutic target.

Two main challenges characterize the future of this research field. First, it is of crucial importance to further characterize ER $\beta$ expression in patients, identifying a specific subset of patients with decreased ER $\beta$ loss or differential expression of ER $\beta$ isoforms, in order to help stratification and patient selection for future therapies targeting estrogen signaling. Some of these questions are currently being investigated (107). Different therapeutic strategies are being studied to selectively target ER $\beta$-dependent signaling, requiring the concomitant development of an appropriate diagnostic companion tool. Second, the down-regulation of ER $\beta$ and the subsequent loss of protective signaling in advanced tumors warrant increased research into the mechanisms involved, to 


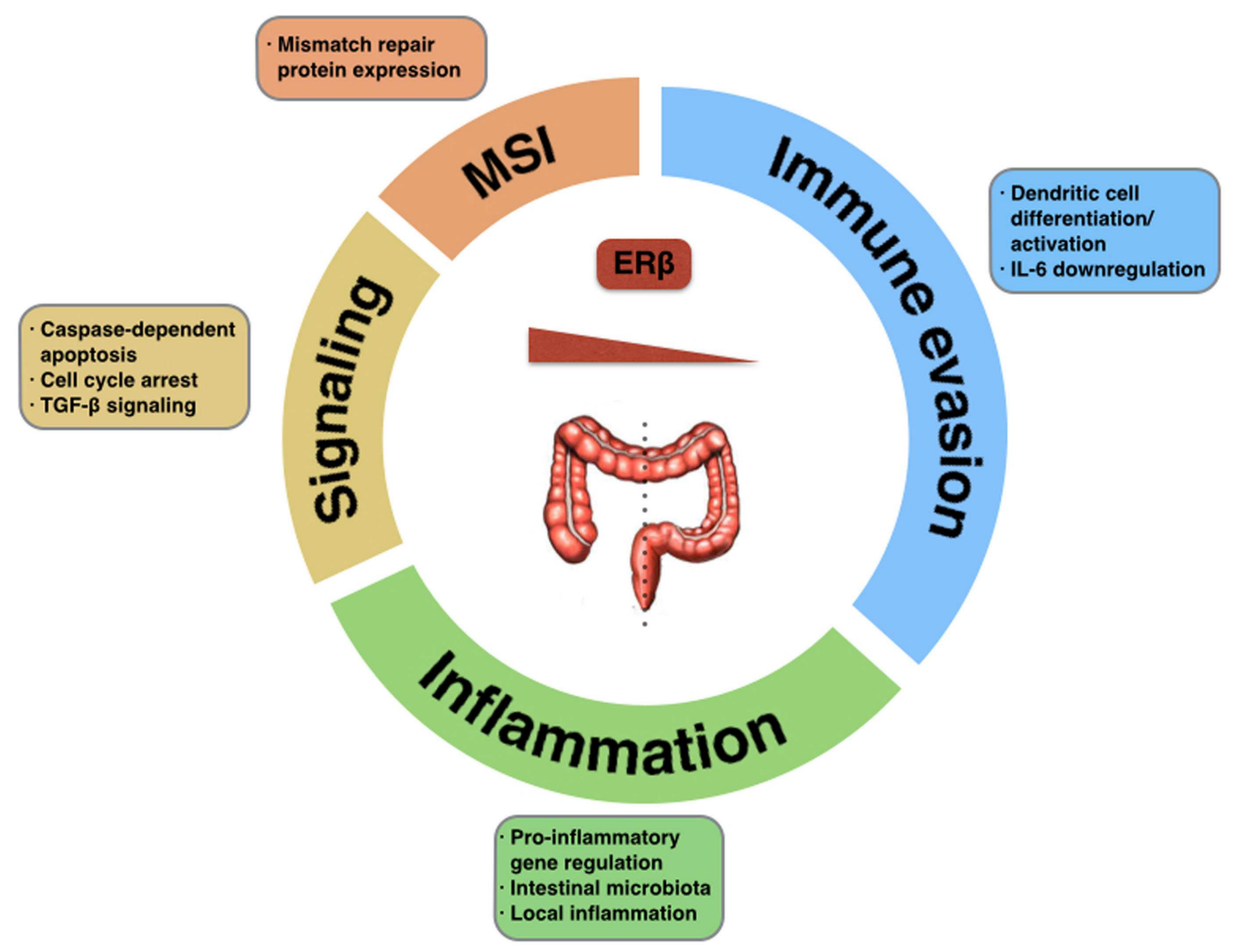

FIGURE 1 |Tumor-suppressive functions of ER $\boldsymbol{\beta}$ in CRC. The potential impact of estrogen signaling through ER $\beta$ in colorectal carcinogenesis could be exerted via activation of pro-apoptotic signaling, regulation of mismatch repair proteins, modulation of the inflammatory tumor microenvironment, activation of immune surveillance mechanisms, or down-regulation of immune evasion mechanisms. Selective loss of $E R \beta$ in different location within the large intestine promotes tumorigenesis. address the potential for therapeutic re-activation of oncosuppressive signaling. A positive feedback mechanism has been described in vitro where estrogen stimulation leads to increased $\mathrm{ER} \beta$ protein expression, reinforcing pro-apoptotic signaling in colon cancer cells (108). This mechanism is lost during colon cancer progression due to unknown factors. Studies in breast cancer, where $\mathrm{ER} \beta$-selective loss is also reported, suggest that epigenetic mechanisms (namely, promoter methylation and histone acetylation) might be involved. Treatment of breast cancer cells with a combination of de-methylating agents and histone deacetylase (HDAC) inhibitors fully restored ER $\beta$ expression (109), and recently a therapeutic approach with combinations of HDAC inhibitors and SERMs (hybrid drugs termed SERMostats) is being investigated in breast cancer (110). In CRC, the adenovirus-mediated induced reexpression of ER $\beta$ showed promising results in pre-clinical studies (111). The design of novel and specific SERMs with selective differential anti-estrogen and estrogen-like activities in different target tissues will greatly advance clinical development of therapeutic strategies for the estrogen pathway. It will be crucial to overcome toxicity issues related to current SERMs and to develop strategies allowing to conserve beneficial estrogen effects in certain tissues while simultaneously targeting signaling involved in cancer initiation and progression. One such strategy has recently emerged, combining SERMs and estrogens in what has been named tissue selective estrogen complex (TSEC), to elicit a blend of ER agonistic activities (112).

\section{ACKNOWLEDGMENTS}

The authors wish to thank past and present members of their laboratory for contributing with data and discussion to the ideas presented in this manuscript.

\section{REFERENCES}

1. Gruber CJ, Tschugguel W, Schneeberger C, Huber JC. Production and actions of estrogens. N Engl J Med (2002) 346:340-52. doi:10.1056/ NEJMra000471

2. Burns KA, Korach KS. Estrogen receptors and human disease: an update. Arch Toxicol (2012) 86:1491-504. doi:10.1007/s00204-012-0868-5

3. Kennelly R, Kavanagh DO, Hogan AM, Winter DC. Oestrogen and the colon: potential mechanisms for cancer prevention. Lancet Oncol (2008) 9:385-91. doi:10.1016/S1470-2045(08)70100-1

4. Ascenzi P, Bocedi A, Marino M. Structure-function relationship of estrogen receptor alpha and beta: impact on human health. Mol Aspects Med (2006) 27:299-402. doi:10.1016/j.mam.2006.07.001

5. Marino M, Caiazza F. Estrogen signal transduction pathways from plasma membrane to the nucleus. In: Grachevsky NO, editor. Signal Transduction Research Trends. New York, NY: Nova Science Publisher (2007). p. 17-44.

6. O'Malley BW. A life-long search for the molecular pathways of steroid hormone action. Mol Endocrinol (2005) 19:1402-11. doi:10.1210/me.2004-0480 
7. Hammes SR, Levin ER. Extranuclear steroid receptors: nature and actions. Endocr Rev (2007) 28:726-41. doi:10.1210/er.2007-0022

8. Björnström L, Sjöberg M. Mechanisms of estrogen receptor signaling: convergence of genomic and nongenomic actions on target genes. Mol Endocrinol (2005) 19:833-42. doi:10.1210/me.2004-0486

9. Levin ER. Extranuclear estrogen receptor's roles in physiology: lessons from mouse models. Am J Physiol Endocrinol Metab (2014) 307:E133-40. doi:10. 1152/ajpendo.00626.2013

10. Castoria G, Migliaccio A, Bilancio A, Di Domenico M, de Falco A, Lombardi M, et al. PI3-kinase in concert with Src promotes the S-phase entry of oestradiol-stimulated MCF-7 cells. EMBO J (2001) 20:6050-9. doi:10.1093/ emboj/20.21.6050

11. Acconcia F, Totta P, Ogawa S, Cardillo I, Inoue S, Leone S, et al. Survival versus apoptotic 17beta-estradiol effect: role of ER alpha and ER beta activated nongenomic signaling. J Cell Physiol (2005) 203:193-201. doi:10.1002/jcp.20219

12. Thomas C, Gustafsson JÅ. The different roles of ER subtypes in cancer biology and therapy. Nat Rev Cancer (2011) 11:597-608. doi:10.1038/nrc3093

13. Galluzzo P, Caiazza F, Moreno S, Marino M. Role of ERbeta palmitoylation in the inhibition of human colon cancer cell proliferation. Endocr Relat Cancer (2007) 14:153-67. doi:10.1677/ERC-06-0020

14. Hamilton KJ, Arao Y, Korach KS. Estrogen hormone physiology: reproductive findings from estrogen receptor mutant mice. Reprod Biol (2014) 14:3-8. doi:10.1016/j.repbio.2013.12.002

15. Saint-Criq V, Rapetti-Mauss R, Yusef YR, Harvey BJ. Estrogen regulation of epithelial ion transport: implications in health and disease. Steroids (2012) 77:918-23. doi:10.1016/j.steroids.2012.02.017

16. Rapetti-Mauss R, O’Mahony F, Sepulveda FV, Urbach V, Harvey BJ. Oestrogen promotes KCNQ1 potassium channel endocytosis and postendocytic trafficking in colonic epithelium. J Physiol (2013) 591:2813-31. doi:10.1113/jphysiol. 2013.251678

17. O’Mahony F, Alzamora R, Chung H-L, Thomas W, Harvey BJ. Genomic priming of the antisecretory response to estrogen in rat distal colon throughout the estrous cycle. Mol Endocrinol (2009) 23:1885-99. doi:10.1210/me.2008-0248

18. Deroo BJ, Korach KS. Estrogen receptors and human disease. J Clin Invest (2006) 116:561-70. doi:10.1172/JCI27987

19. Jordan VC. Chemoprevention of breast cancer with selective oestrogenreceptor modulators. Nat Rev Cancer (2007) 7:46-53. doi:10.1038/nrc2048

20. Syed V, Ulinski G, Mok SC, Yiu GK, Ho S-M. Expression of gonadotropin receptor and growth responses to key reproductive hormones in normal and malignant human ovarian surface epithelial cells. Cancer Res (2001) 61:6768-76.

21. Zannoni GF, Monterossi G, De Stefano I, Gargini A, Salerno MG, Farulla I, et al. The expression ratios of estrogen receptor $\alpha(\mathrm{ER} \alpha)$ to estrogen receptor $\beta 1(\mathrm{ER} \beta 1)$ and $\mathrm{ER} \alpha$ to ER $\beta 2$ identify poor clinical outcome in endometrioid endometrial cancer. Hum Pathol (2013) 44:1047-54. doi:10.1016/j.humpath. 2012.09.007

22. Härkönen PL, Mäkelä SI. Role of estrogens in development of prostate cancer. J Steroid Biochem Mol Biol (2004) 92:297-305. doi:10.1016/j.jsbmb.2004.10.016

23. Siegfried JM. Smoking out reproductive hormone actions in lung cancer. $\mathrm{Mol}$ Cancer Res (2014) 12:24-31. doi:10.1158/1541-7786.MCR-13-0580

24. Hogan AM, Collins D, Baird AW, Winter DC. Estrogen and gastrointestinal malignancy. Mol Cell Endocrinol (2009) 307:19-24. doi:10.1016/j.mce.2009. 03.016

25. Jordan VC, Brodie AMH. Development and evolution of therapies targeted to the estrogen receptor for the treatment and prevention of breast cancer. Steroids (2007) 72:7-25. doi:10.1016/j.steroids.2006.10.009

26. Stabile LP, Davis ALG, Gubish CT, Hopkins TM, Luketich JD, Christie N, et al. Human non-small cell lung tumors and cells derived from normal lung express both estrogen receptor alpha and beta and show biological responses to estrogen. Cancer Res (2002) 62:2141-50.

27. Olivo-Marston SE, Mechanic LE, Mollerup S, Bowman ED, Remaley AT, Forman MR, et al. Serum estrogen and tumor-positive estrogen receptor-alpha are strong prognostic classifiers of non-small-cell lung cancer survival in both men and women. Carcinogenesis (2010) 31:1778-86. doi:10.1093/carcin/bgq156

28. Risbridger GP, Davis ID, Birrell SN, Tilley WD. Breast and prostate cancer: more similar than different. Nat Rev Cancer (2010) 10:205-12. doi:10.1038/nrc2795

29. Dey P, Barros RPA, Warner M, Ström A, Gustafsson JÅ. Insight into the mechanisms of action of estrogen receptor $\beta$ in the breast, prostate, colon, and CNS. J Mol Endocrinol (2013) 51:T61-74. doi:10.1530/JME-13-0150
30. Hapangama DK, Kamal AM, Bulmer JN. Estrogen receptor $\beta$ : the guardian of the endometrium. Hum Reprod Update (2014). doi:10.1093/humupd/dmu053

31. Bossard C, Busson M, Vindrieux D, Gaudin F, Machelon V, Brigitte M, et al. Potential role of estrogen receptor beta as a tumor suppressor of epithelial ovarian cancer. PLoS One (2012) 7:e44787. doi:10.1371/journal.pone.0044787

32. Elbanna HG, Ebrahim MA, Abbas AM, Zalata K, Hashim MA. Potential value of estrogen receptor beta expression in colorectal carcinoma: interaction with apoptotic index. J Gastrointest Cancer (2012) 43:56-62. doi:10.1007/s12029010-9214-4

33. Konstantinopoulos PA, Kominea A, Vandoros G, Sykiotis GP, Andricopoulos $\mathrm{P}$, Varakis I, et al. Oestrogen receptor beta (ERbeta) is abundantly expressed in normal colonic mucosa, but declines in colon adenocarcinoma paralleling the tumour's dedifferentiation. Eur J Cancer (2003) 39:1251-8. doi:10.1016/ S0959-8049(03)00239-9

34. Foley EF, Jazaeri AA, Shupnik MA, Jazaeri O, Rice LW. Selective loss of estrogen receptor beta in malignant human colon. Cancer Res (2000) 60:245-8.

35. Rudolph A, Toth C, Hoffmeister M, Roth W, Herpel E, Jansen L, et al. Expression of oestrogen receptor $\beta$ and prognosis of colorectal cancer. $\mathrm{Br}$ J Cancer (2012) 107:831-9. doi:10.1038/bjc.2012.323

36. Jassam N, Bell SM, Speirs V, Quirke P. Loss of expression of oestrogen receptor beta in colon cancer and its association with Dukes' staging. Oncol Rep (2005) 14:17-21. doi:10.3892/or.14.1.17

37. Hartman J, Edvardsson K, Lindberg K, Zhao C, Williams C, Ström A, et al. Tumor repressive functions of estrogen receptor beta in SW480 colon cancer cells. Cancer Res (2009) 69:6100-6. doi:10.1158/0008-5472.CAN-09-0506

38. Jemal A, Bray F, Center MM, Ferlay J, Ward E, Forman D. Global cancer statistics. CA Cancer J Clin (2011) 61:69-90. doi:10.3322/caac.20107

39. Ferlay J, Soerjomataram I, Dikshit R, Eser S, Mathers C, Rebelo M, et al. Cancer incidence and mortality worldwide: sources, methods and major patterns in GLOBOCAN 2012. Int J Cancer (2014) 136(5):E359-86. doi:10.1002/ijc.29210

40. Ferlay J, Soerjomataram I, Ervik M, Dikshit R, Eser S, Mathers C, et al. GLOBOCAN 2012 v1.0, Cancer Incidence and Mortality Worldwide: IARC CancerBase No. 11. globocaniarcfr. (2014). Available from: http://globocan.iarc.fr

41. Chlebowski RT, Wactawski-Wende J, Ritenbaugh C, Hubbell FA, Ascensao J, Rodabough RJ, et al. Estrogen plus progestin and colorectal cancer in postmenopausal women. N Engl J Med (2004) 350:991-1004. doi:10.1056/ NEJMoa032071

42. Simon MS, Chlebowski RT, Wactawski-Wende J, Johnson KC, Muskovitz A, Kato I, et al. Estrogen plus progestin and colorectal cancer incidence and mortality. J Clin Oncol (2012) 30:3983-90. doi:10.1200/JCO.2012.42.7732

43. Barzi A, Lenz AM, Labonte MJ, Lenz H-J. Molecular pathways: estrogen pathway in colorectal cancer. Clin Cancer Res (2013) 19:5842-8. doi:10.1158/10780432.CCR-13-0325

44. Rudolph A, Toth C, Hoffmeister M, Roth W, Herpel E, Schirmacher P, et al. Colorectal cancer risk associated with hormone use varies by expression of estrogen receptor- $\beta$. Cancer Res (2013) 73:3306-15. doi:10.1158/0008-5472. CAN-12-4051

45. Ogino S, Chan AT, Fuchs CS, Giovannucci E. Molecular pathological epidemiology of colorectal neoplasia: an emerging transdisciplinary and interdisciplinary field. Gut (2011) 60:397-411. doi:10.1136/gut.2010.217182

46. Lin JH, Morikawa T, Chan AT, Kuchiba A, Shima K, Nosho K, et al. Postmenopausal hormone therapy is associated with a reduced risk of colorectal cancer lacking CDKN1A expression. Cancer Res (2012) 72:3020-8. doi:10.1158/0008-5472.CAN-11-2619

47. Wu AH, Siegmund KD, Long TI, Cozen W, Wan P, Tseng C-C, et al. Hormone therapy, DNA methylation and colon cancer. Carcinogenesis (2010) 31:1060-7. doi:10.1093/carcin/bgq009

48. Limburg PJ, Limsui D, Vierkant RA, Tillmans LS, Wang AH, Lynch CF, et al. Postmenopausal hormone therapy and colorectal cancer risk in relation to somatic KRAS mutation status among older women. Cancer Epidemiol Biomarkers Prev (2012) 21:681-4. doi:10.1158/1055-9965.EPI-11-1168

49. Limsui D, Vierkant RA, Tillmans LS, Wang AH, Weisenberger DJ, Laird PW, et al. Postmenopausal hormone therapy and colorectal cancer risk by molecularly defined subtypes among older women. Gut (2012) 61:1299-305. doi:10.1136/gutjnl-2011-300719

50. Yan L, Spitznagel EL, Bosland MC. Soy consumption and colorectal cancer risk in humans: a meta-analysis. Cancer Epidemiol Biomarkers Prev (2010) 19:148-58. doi:10.1158/1055-9965.EPI-09-0856 
51. Guo J-Y, Li X, Browning JD, Rottinghaus GE, Lubahn DB, Constantinou A, et al. Dietary soy isoflavones and estrone protect ovariectomized ERalphaKO and wild-type mice from carcinogen-induced colon cancer. J Nutr (2004) 134:179-82.

52. Flood DM, Weiss NS, Cook LS, Emerson JC, Schwartz SM, Potter JD. Colorectal cancer incidence in Asian migrants to the United States and their descendants. Cancer Causes Control (2000) 11:403-11. doi:10.1023/A:1008955722425

53. Kim S-E, Shim K-N, Jung S-A, Yoo K, Moon IH. An association between obesity and the prevalence of colonic adenoma according to age and gender. J Gastroenterol (2007) 42:616-23. doi:10.1007/s00535-007-2074-4

54. Aleksandrova K, Drogan D, Boeing H, Jenab M, Bas Bueno-de-Mesquita H, Jansen E, et al. Adiposity, mediating biomarkers and risk of colon cancer in the European prospective investigation into cancer and nutrition study. Int J Cancer (2013) 134:612-21. doi:10.1002/ijc.28368

55. Yakar S, Nunez NP, Pennisi P, Brodt P, Sun H, Fallavollita L, et al. Increased tumor growth in mice with diet-induced obesity: impact of ovarian hormones. Endocrinology (2006) 147:5826-34. doi:10.1210/en.2006-0311

56. Sikalidis AK, Varamini B. Roles of hormones and signaling molecules in describing the relationship between obesity and colon cancer. Pathol Oncol Res (2011) 17:785-90. doi:10.1007/s12253-010-9352-9

57. Ho GYF, Wang T, Gunter MJ, Strickler HD, Cushman M, Kaplan RC, et al. Adipokines linking obesity with colorectal cancer risk in postmenopausal women. Cancer Res (2012) 72:3029-37. doi:10.1158/0008-5472.CAN-11-2771

58. Yi KW, Shin J-H, Seo HS, Lee JK, Oh M-J, Kim T, et al. Role of estrogen receptoralpha and -beta in regulating leptin expression in 3T3-L1 adipocytes. Obesity (Silver Spring) (2008) 16:2393-9. doi:10.1038/oby.2008.389

59. McTiernan A. Mechanisms linking physical activity with cancer. Nat Rev Cancer (2008) 8:205-11. doi:10.1038/nrc2325

60. Xie L-Q, Yu J-P, Luo H-S. Expression of estrogen receptor beta in human colorectal cancer. World J Gastroenterol (2004) 10:214-7.

61. Passarelli MN, Phipps AI, Potter JD, Makar KW, Coghill AE, Wernli KJ, et al. Common single-nucleotide polymorphisms in the estrogen receptor $\beta$ promoter are associated with colorectal cancer survival in postmenopausal women. Cancer Res (2013) 73:767-75. doi:10.1158/0008-5472. CAN-12-2484

62. Grivas PD, Tzelepi V, Sotiropoulou-Bonikou G, Kefalopoulou Z, Papavassiliou $\mathrm{AG}$, Kalofonos H. Estrogen receptor $\alpha / \beta$, AIB1, and TIF2 in colorectal carcinogenesis: do coregulators have prognostic significance? Int J Colorectal Dis (2009) 24:613-22. doi:10.1007/s00384-009-0647-9

63. Wada-Hiraike O, Imamov O, Hiraike H, Hultenby K, Schwend T, Omoto Y, et al. Role of estrogen receptor beta in colonic epithelium. Proc Natl Acad Sci USA (2006) 103:2959-64. doi:10.1073/pnas.0511271103

64. Saleiro D, Murillo G, Benya RV, Bissonnette M, Hart J, Mehta RG. Estrogen receptor- $\beta$ protects against colitis-associated neoplasia in mice. Int $J$ Cancer (2012) 131:2553-61. doi:10.1002/ijc.27578

65. Giroux V, Lemay F, Bernatchez G, Robitaille Y, Carrier JC. Estrogen receptor beta deficiency enhances small intestinal tumorigenesis in ApcMin/+ mice. Int J Cancer (2008) 123:303-11. doi:10.1002/ijc.23532

66. Tu Z, Ma Y, Tian J, Li H, Akers W, Achilefu S, et al. Estrogen receptor $\beta$ potentiates the antiproliferative effect of raloxifene and affects the cell migration and invasion in HCT-116 colon cancer cells. J Cancer Res Clin Oncol (2012) 138:1091-103. doi:10.1007/s00432-011-1145-3

67. Janakiram NB, Mohammed A, Brewer M, Bryant T, Biddick L, Lightfoot S, et al. Raloxifene and antiestrogenic gonadorelin inhibits intestinal tumorigenesis by modulating immune cells and decreasing stem-like cells. Cancer Prev Res (Phila) (2014) 7:300-9. doi:10.1158/1940-6207.CAPR-13-0345

68. Armstrong CM, Billimek AR, Allred KF, Sturino JM, Weeks BR, Allred CD. A novel shift in estrogen receptor expression occurs as estradiol suppresses inflammation-associated colon tumor formation. Endocr Relat Cancer (2013) 20:515-25. doi:10.1530/ERC-12-0308

69. Kramer F, Johnson IT, Doleman JF, Lund EK. A comparison of the effects of soya isoflavonoids and fish oil on cell proliferation, apoptosis and the expression of oestrogen receptors alpha and beta in the mammary gland and colon of the rat. Br J Nutr (2009) 102:29-36. doi:10.1017/S0007114508137862

70. Weyant MJ, Carothers AM, Mahmoud NN, Bradlow HL, Remotti H, Bilinski RT, et al. Reciprocal expression of ERalpha and ERbeta is associated with estrogen-mediated modulation of intestinal tumorigenesis. Cancer Res (2001) 61:2547-51.
71. Moore JT, McKee DD, Slentz-Kesler K, Moore LB, Jones SA, Horne EL, et al. Cloning and characterization of human estrogen receptor beta isoforms. Biochem Biophys Res Commun (1998) 247:75-8. doi:10.1006/bbrc.1998.8738

72. Leung Y-K, Mak P, Hassan S, Ho S-M. Estrogen receptor (ER)-beta isoforms: a key to understanding ER-beta signaling. Proc Natl Acad Sci USA (2006) 103:13162-7. doi:10.1073/pnas.0605676103

73. Fiorelli G, Picariello L, Martineti V, Tonelli F, Brandi ML. Functional estrogen receptor beta in colon cancer cells. Biochem Biophys Res Commun (1999) 261:521-7. doi:10.1006/bbrc.1999.1062

74. Wong NACS, Malcomson RDG, Jodrell DI, Groome NP, Harrison DJ, Saunders PTK. ERbeta isoform expression in colorectal carcinoma: an in vivo and in vitro study of clinicopathological and molecular correlates. J Pathol (2005) 207:53-60. doi:10.1002/path.1807

75. Benedix F, Kube R, Meyer F, Schmidt U, Gastinger I, Lippert H, et al. Comparison of 17,641 patients with right- and left-sided colon cancer: differences in epidemiology, perioperative course, histology, and survival. Dis Colon Rectum (2010) 53:57-64. doi:10.1007/DCR.0b013e3181c703a4

76. Sugai T, Habano W, Jiao Y-F, Tsukahara M, Takeda Y, Otsuka K, et al. Analysis of molecular alterations in left- and right-sided colorectal carcinomas reveals distinct pathways of carcinogenesis: proposal for new molecular profile of colorectal carcinomas. J Mol Diagn (2006) 8:193-201. doi:10.2353/jmoldx.2006. 050052

77. Nawa T, Kato J, Kawamoto H, Okada H, Yamamoto H, Kohno H, et al. Differences between right- and left-sided colon cancer in patient characteristics, cancer morphology and histology. J Gastroenterol Hepatol (2008) 23:418-23. doi:10.1111/j.1440-1746.2007.04923.x

78. Iacopetta B. Are there two sides to colorectal cancer? Int J Cancer (2002) 101:403-8. doi:10.1002/ijc.10635

79. Missiaglia E, Jacobs B, D’Ario G, Di Narzo AF, Soneson C, Budinska E, et al. Distal and proximal colon cancers differ in terms of molecular, pathological, and clinical features. Ann Oncol (2014) 25:1995-2001. doi:10.1093/annonc/ mdu275

80. Koo JH, Leong RWL. Sex differences in epidemiological, clinical and pathological characteristics of colorectal cancer. J Gastroenterol Hepatol (2010) 25:33-42. doi:10.1111/j.1440-1746.2009.05992.x

81. Ward R, Meagher A, Tomlinson I, O'Connor T, Norrie M, Wu R, et al. Microsatellite instability and the clinicopathological features of sporadic colorectal cancer. Gut (2001) 48:821-9. doi:10.1136/gut.48.6.821

82. Slattery ML, Potter JD, Curtin K, Edwards S, Ma KN, Anderson K, et al. Estrogens reduce and withdrawal of estrogens increase risk of microsatellite instability-positive colon cancer. Cancer Res (2001) 61:126-30.

83. He Y-Q, Sheng J-Q, Ling X-L, Fu L, Jin P, Yen L, et al. Estradiol regulates miR-135b and mismatch repair gene expressions via estrogen receptor$\beta$ in colorectal cells. Exp Mol Med (2012) 44:723. doi:10.3858/emm.2012.44. 12.079

84. Goldstone R, Itzkowitz S, Harpaz N, Ullman T. Progression of low-grade dysplasia in ulcerative colitis: effect of colonic location. Gastrointest Endosc (2011) 74:1087-93. doi:10.1016/j.gie.2011.06.028

85. Yamauchi M, Lochhead P, Morikawa T, Huttenhower C, Chan AT, Giovannucci E, et al. Colorectal cancer: a tale of two sides or a continuum? Gut (2012) 61:794-7. doi:10.1136/gutjnl-2012-302014

86. Yamauchi M, Morikawa T, Kuchiba A, Imamura Y, Qian ZR, Nishihara R, et al. Assessment of colorectal cancer molecular features along bowel subsites challenges the conception of distinct dichotomy of proximal versus distal colorectum. Gut (2012) 61:847-54. doi:10.1136/gutjnl-2011-300865

87. Rosty C, Young JP, Walsh MD, Clendenning M, Sanderson K, Walters RJ, et al. PIK3CA activating mutation in colorectal carcinoma: associations with molecular features and survival. PLoS One (2013) 8:e65479. doi:10.1371/journal. pone.0065479

88. Phipps AI, Chan AT, Ogino S. Anatomic subsite of primary colorectal cancer and subsequent risk and distribution of second cancers. Cancer (2013) 119:3140-7. doi:10.1002/cncr.28076

89. Parmeggiani D, Avenia N, Gubitosi A, Gilio F, Atelli PF, Agresti M. Additional prognostic factors in right colon cancer staging. Updates Surg (2011) 63:155-61. doi:10.1007/s13304-011-0078-3

90. Pollard KM. Gender differences in autoimmunity associated with exposure to environmental factors. J Autoimmun (2012) 38:J177-86. doi:10.1016/j.jaut. 2011.11.007 
91. Saleh M, Trinchieri G. Innate immune mechanisms of colitis and colitisassociated colorectal cancer. Nat Rev Immunol (2010) 11:9-20. doi:10.1038/ nri2891

92. Vesely MD, Kershaw MH, Schreiber RD, Smyth MJ. Natural innate and adaptive immunity to cancer. Annu Rev Immunol (2011) 29:235-71. doi:10.1146/ annurev-immunol-031210-101324

93. Edvardsson K, Ström A, Jonsson P, Gustafsson JA, Williams C. Estrogen receptor $\beta$ induces antiinflammatory and antitumorigenic networks in colon cancer cells. Mol Endocrinol (2011) 25:969-79. doi:10.1210/me.2010-0452

94. Zhu L, Cheng X, Ding Y, Shi J, Jin H, Wang H, et al. Bone marrow-derived myofibroblasts promote colon tumorigenesis through the IL-6/JAK2/STAT3 pathway. Cancer Lett (2014) 343:80-9. doi:10.1016/j.canlet.2013.09.017

95. Grivennikov S, Karin E, Terzic J, Mucida D, Yu G-Y, Vallabhapurapu S, et al. IL-6 and Stat3 are required for survival of intestinal epithelial cells and development of colitis-associated cancer. Cancer Cell (2009) 15:103-13. doi:10.1016/j.ccr.2009.01.001

96. Kovats S, Carreras E. Regulation of dendritic cell differentiation and function by estrogen receptor ligands. Cell Immunol (2008) 252:81-90. doi:10.1016/j. cellimm.2007.10.008

97. Carreras E, Turner S, Frank MB, Knowlton N, Osban J, Centola M, et al. Estrogen receptor signaling promotes dendritic cell differentiation by increasing expression of the transcription factor IRF4. Blood (2010) 115:238-46. doi:10.1182/blood-2009-08-236935

98. Bengtsson AK, Ryan EJ, Giordano D, Magaletti DM, Clark EA. 17beta-estradiol (E2) modulates cytokine and chemokine expression in human monocytederived dendritic cells. Blood (2004) 104:1404-10. doi:10.1182/blood-200310-3380

99. Cvoro A, Tatomer D, Tee M-K, Zogovic T, Harris HA, Leitman DC. Selective estrogen receptor-beta agonists repress transcription of proinflammatory genes. J Immunol (2008) 180:630-6. doi:10.4049/jimmunol.180.1.630

100. Simard J, Gingras S. Crucial role of cytokines in sex steroid formation in normal and tumoral tissues. Mol Cell Endocrinol (2001) 171:25-40. doi:10.1016/ S0303-7207(00)00387-7

101. Menon R, Watson SE, Thomas LN, Allred CD, Dabney A, Azcarate-Peril MA, et al. Diet complexity and estrogen receptor $\beta$ status affect the composition of the murine intestinal microbiota. Appl Environ Microbiol (2013) 79:5763. doi:10.1128/AEM.01182-13

102. Totta P, Acconcia F, Leone S, Cardillo I, Marino M. Mechanisms of naringenininduced apoptotic cascade in cancer cells: involvement of estrogen receptor alpha and beta signalling. IUBMB Life (2004) 56:491-9. doi:10.1080/ 15216540400010792

103. Bulzomi P, Galluzzo P, Bolli A, Leone S, Acconcia F, Marino M. The proapoptotic effect of quercetin in cancer cell lines requires ER $\beta$-dependent signals. J Cell Physiol (2012) 227:1891-8. doi:10.1002/jcp.22917

104. Bolli A, Bulzomi P, Galluzzo P, Acconcia F, Marino M. Bisphenol A impairs estradiol-induced protective effects against DLD-1 colon cancer cell growth. IUBMB Life (2010) 62:684-7. doi:10.1002/iub.370
105. Diamanti-Kandarakis E, Bourguignon JP, Giudice LC, Hauser R, Prins GS, Soto AM, et al. Endocrine-disrupting chemicals: an endocrine society scientific statement. Endocr Rev (2009) 30:293-342. doi:10.1210/er.2009-0002

106. Bolli A, Marino M. Current and future development of estrogen receptor ligands: applications in estrogen-related cancers. Recent Pat Endocr Metab Immune Drug Discov (2011) 5:210-29. doi:10.2174/187221411797265881

107. van Halteren H, Mulder D, Ruijter E. Oestrogen receptor-beta as a potential target for treatment in advanced colorectal cancer: a pilot study. Histopathology (2014) 64:787-90. doi:10.1111/his.12340

108. Caiazza F, Galluzzo P, Lorenzetti S, Marino M. 17Beta-estradiol induces ERbeta up-regulation via p38/MAPK activation in colon cancer cells. Biochem Biophys Res Commun (2007) 359:102-7. doi:10.1016/j.bbrc.2007.05.059

109. Al-Nakhle H, Smith L, Bell SM, Burns PA, Cummings M, Hanby AM, et al. Regulation of estrogen receptor $\beta 1$ expression in breast cancer by epigenetic modification of the $5^{\prime}$ regulatory region. Int J Oncol (2013) 43:2039-45. doi:10.3892/ijo.2013.2112

110. Patel HK, Siklos MI, Abdelkarim H, Mendonca EL, Vaidya A, Petukhov PA, et al. A chimeric SERM-histone deacetylase inhibitor approach to breast cancer therapy. ChemMedChem (2014) 9:602-13. doi:10.1002/cmdc.201300270

111. Tu Z, Ma Y, Akers W, Achilefu S, Gu Y. Therapeutic effect of the treatment for colorectal cancer with adenoviral vectors mediated estrogen receptor $\beta$ gene therapy combined with thermotherapy. J Cancer Res Clin Oncol (2014) 140:623-32. doi:10.1007/s00432-014-1611-9

112. Wardell SE, Nelson ER, McDonnell DP. From empirical to mechanism-based discovery of clinically useful selective estrogen receptor modulators (SERMs). Steroids (2014) 90:30-8. doi:10.1016/j.steroids.2014.07.013

Conflict of Interest Statement: Francesco Caiazza is supported by a Newman Fellowship awarded by the UCD Foundation and funded by a donation from Merck Serono. The authors have no other relevant affiliations or financial involvement with any organization or entity with a financial interest in or financial conflict with the subject matter or materials discussed in the manuscript.

Received: 07 November 2014; accepted: 16 January 2015; published online: 02 February 2015.

Citation: Caiazza F, Ryan EJ, Doherty G, Winter DC and Sheahan K (2015) Estrogen receptors and their implications in colorectal carcinogenesis. Front. Oncol. 5:19. doi: 10.3389/fonc.2015.00019

This article was submitted to Gastrointestinal Cancers, a section of the journal Frontiers in Oncology.

Copyright (C) 2015 Caiazza, Ryan, Doherty, Winter and Sheahan. This is an openaccess article distributed under the terms of the Creative Commons Attribution License (CC BY). The use, distribution or reproduction in other forums is permitted, provided the original author(s) or licensor are credited and that the original publication in this journal is cited, in accordance with accepted academic practice. No use, distribution or reproduction is permitted which does not comply with these terms. 